\title{
Alat Pencetak Edible Straw berbasis Mikrokontroler
}

\author{
ANAK AGUNG GDE EKAYANA, I GEDE AGUS ARI SANTIKA
}

Sistem Komputer, STMIK STIKOM Indonesia, Indonesia

Email: gungekayana@stiki-indonesia.ac.id

Received 17 Mei 2021 | Revised 8 Juni 2021 | Accepted 14 Juli 2021

\begin{abstract}
ABSTRAK
Penggunaan plastik saat ini banyak digunakan diberbagai kegiatan masyarakat, dampak dari penggunaan plastik terlalu banyak menyebabkan polusi pada lingkungan. Penelitian ini bertujuan merancang dan membangun alat yang menghasilkan sedotan minuman dengan bahan yang ramah lingkungan, bahan yang digunakan menggunakan agar-agar rumput laut nutrijell yang aman untuk dikonsumsi. Alat pencetak sedotan dirancang menggunakan komponen elektronika, diantaranya sensor suhu DS18B20, mikrokontroler, elemen pemanas dan kipas. Tahapan dalam proses rancang bangun meliputi perancangan mekanik, material cetakan menggunakan stainless steel, perancangan sistem elektronika dan perancangan perangkat lunak. Hasil pengujian dari alat pencetak edible straw mendapatkan hasil sedotan yang bervariasi dari segi bentuk dan tekstur, pada proses kerjanya alat pencetak sedotan dapat mengatur waktu pemanas dari kisaran waktu 5 - 30 menit, sedotan tersebut dipanaskan selama 30 menit dari suhu awal dengan suhu terukur pada menit ke-30 adalah $62^{\circ} \mathrm{C}$.
\end{abstract}

Kata kunci: edible, sedotan, pemanas, mikrokontroler, agar-agar nutrijell

\begin{abstract}
The use of plastic is currently widely used in various community activities, the impact of using too much plastic causes pollution to the environment. This study aims to design and build a device that produces drinking straws with environmentally friendly materials, the materials used are using nutrijell seaweed jelly which is safe for consumption. The straw printer is designed using electronic components, including the DS18B20 temperature sensor, microcontroller, heating element and fan. The stages in the design process include mechanical design, mold material using stainless steel, electronic system design and software design. The test results from the edible straw printer get straws that vary in terms of shape and texture, in the working process the straw printer can set the heating time from a time range of 5-30 minutes, the straws are heated for 30 minutes from the initial temperature with a measured temperature in minutes 30 th is $62^{\circ} \mathrm{C}$.
\end{abstract}

Keywords: edible, straw, heater, microcontroller, nutrijell jelly 


\section{PENDAhUlUAN}

Limbah plastik dari tahun ke tahun selalu menjadi permasalahan yang serius dan sering menjadi pembahasan di seluruh dunia. Dampak dari sampah plastik tentunya akan berimbas pada lingkungan tempat tinggal karena sulitnya sampah plastik untuk terurai. Hasil penelitian yang dilakukan Pratama yang berjudul Perancangan Motion Graphic Dampak Plastik di laut (Pratama, 2020), menjelaskan bahwa Indonesia dijuluki Negara Kepulauan masih menjadi negara penghasil sampah plastik terbesar kedua di dunia. Semakin banyak masyarakat menggunakan plastik sekali pakai, seperti kantong plastik, botol kemasan plastik dan sedotan plastik tentunya akan berdampak pada kesehatan manusia dan juga jika volume sampah plastik terlalu banyak dan pembuangannya tidak pada tempat yang tepat, penelitian yang dilakukan oleh Qomatiah yang berjudul Sosialisasi Pengurangan Bahan Plastik di Masyarakat (Qomariah, 2020), menjelaskan dampak plastik bagi lingkungan akan menyebabkan penyumbatan saluran air. Pulau Bali dengan keindahan alam dan keunikan budayanya menjadikan Bali sebagai destinasi Daya Tarik Wisata (DTW) bagi wisatawan mancanegara, tentunya hal ini harus menjadi perhatian bagi pengelola pariwisata dan pemerintahan terkait, karena semakin banyaknya wisatawan yang datang, pastinya sampah yang dhasilkan juga semakin banyak.

Peraturan Daerah Nomor 5 Tahun 2011 tentang pengelolaan sampah dan Peraturan Gubernur Bali Nomor 97 Tahun 2018 tentang pembatasan timbulan sampah plastik sekali pakai, peraturan tersebut menjadi dasar untuk berpikir dan ide inovasi terkait mengurangi penggunaan sampah plastik sekali pakai. Permasalahan terkait sampah plastik sekali pakai sudah seharusnya diberikan solusi untuk dapat mengurangi timbulan sampah tersebut, tentunya masyarakat dan pemerintah tidak bisa langsung begitu saja untuk tidak menggunakan plastik, tetapi salah satu inovasi yang dapat dilakukan adalah mengubah dari plastik menjadi ramah lingkungan. Inovasi ini difokuskan untuk mengurangi timbulan sampah dari sedotan plastik, karena kita ketahui bersama saat ini sedang trend minuman kopi dan coffeshop (Dahwilani, 2019). Pipet atau sedotan plastik yang jumlahnya semakin banyak, tentunya menyebabkan kapasitas sampah di Bali menjadi semakin meningkat.

Penelitian alat pencetak edible straw berbasis mikrokontroler dalam proses rancang bangunnya didukung dari beberapa sumber yang relevan agar hasil dari penelitian dapat menghasilkan data yang valid dan reliabel. Penelitian yang dilakukan oleh Nugroho,dkk yang berjudul Prototype Mesin CNC 2D Berbasis Arduino Uno (Nugroho, dkk, 2019), pada hasil penelitian tersebut yang diambil adalah proses pembuatan mekanik alat prototype yang nantinya sebagai bahan pembuatan boks alat pencetak sedotan, sehingga dapat dibuat portable dan dapat digunakan dengan maksimal. Hasil penelitian yang dilakukan oleh Ekayana yang berjudul Rancang Bangun Alat Pengering Rumput Laut Berbasis Mikrokontroler Arduino Uno (Ekayana, 2016), pada artikel tersebut yang diambil adalah karakteristik pengeringan rumput laut dengan elemen pemanas yang digunakan dan sistem pewaktuan pemanas, yang nantinya digunakan dalam pembuatan sirkuit elektronika pada alat pencetak sedotan ramah lingkungan. Hasil penelitian oleh Sujana, dkk yang berjudul Pemberdayaan Ekonomi Masyarakat Pesisir Melalui Pengolahan Rumput Laut (Sujana, dkk, 2020), menjelaskan bahwa rumput laut banyak digunakan sebagai olahan makanan dengan tambahan kreativitas untuk menjadi suatu bentuk kuliner yang baru. Hal yang sama juga disampaikan pada hasil penelitian Zainudin, dkk yang berjudul Pemanfaatan Alat Monitoring Kadar Air pada Gabah untuk Peningkatan Kualitas Panen (Zainudin, dkk, 2020), dari artikel tersebut yang didapatkan adalah penggunaan sensor kelembapan yang memiliki sensitivitas dan tanggapan waktu yang baik dalam mengukur tingkat kelembapan air dari suatu objek. Hasil penelitian dari Wirajaya, dkk yang berjudul Rancang Bangun Mesin Penetas Telur Otomatis Menggunakan 
Mikrokontroler Arduino Uno (Wirajaya, dkk, 2020), dalam artikel tersebut mengambil literasi data terkait mikrokontroler Arduino Uno yang digunakan untuk dapat dikolaborasikan dengan penelitian yang akan disusun.

Penggunaan sedotan plastik dalam keseharianya selain menimbulkan pencemaran lingkungan, juga memberi dampak yang tidak baik untuk kesehatan, walaupun beberapa tahun lalu ada pengembangan sedotan dari bahan stainless stee/ dan kertas, tetap saja ada dampak negatif dari penggunaan yang terus menerus. Berdasarkan permasalahan yang telah dijabarkan di atas, belum terdapat studi adanya alat pencetak sedotan organik (edible straw) dengan menggunakan bahan makanan seperti rumput laut, hasil penelitian yang dilakukan oleh Rusli yang berjudul Strategi Pengelolaan Budi Daya Rumput Laut Kappaphycus Alvarezii (Rusli, dkk, 2020), menjelaskan bahwa rumput laut dapat diolah untuk membuat inovasi pangan baru berbahan rumput laut, oleh karena itu diperlukannya suatu alat yang mampu mencetak sedotan organik menggunakan bahan makanan dengan spesifikasi bahan yang digunakan sudah berstandar BPOM, guna menjadi solusi mengurangi penggunaan sedotan plastik sekali pakai. Alat yang dibuat menggunakan komponen-komponen elektronika dan mikrokontroler sebagai bahan penyusunnya, dan alat pencetak dapat digunakan di manapun (portabel) sehingga tidak memakan ruang yang banyak. Inovasi pembuatan alat pencetak edible straw berupaya membantu khususnya Bali untuk dapat mengurangi timbulan sampah sekali pakai, dan untuk Indonesia pada umumnya membantu mengurangi kapasitas jumlah sampah plastik.

\section{METODOLOGI PENELITIAN}

\subsection{Perancangan Umum Alat}

Metode penelitian yang digunakan adalah rancang dan membangun, alat pencetak edible straw berbasis mikrokontroler menggunakan beberapa komponen utama di dalam perancangannya, adapun penjabaran dari komponen yang digunakan yaitu, sensor suhu DS18B20 sebagai input untuk mengukur tingkat parameter suhu di dalam boks alat pencetak sedotan, hasil penelitian yang dilakukan oleh Aritonang, dkk yang berjudul Implementasi Sensor Suhu DS18B20 dan Sensor Tekanan MPX5700AP menggunakan Mikrokontroller Arduino Pada Alat Pendeteksi Tingkat Stress (Aritonang, dkk, 2021), menjelaskan bahwa penggunaan sensor DS18B20 melihat dari karakteristik fisik sensor yang solid, tahan air dan memiliki akurasi kesalahan $\pm 0.5^{\circ} \mathrm{C}$. Komponen push button digunakan sebagai tombol pengatur waktu pemanas dan pendinginan alat pencetak, pengaturan waktu pemanas pada alat direncanakan memiliki jarak 5 menit sampai 30 menit. Mikrokontroler Arduino Uno sebagai pusat pemroses data input dan output, Arduino Uno digunakan bertujuan lebih memudahkan dalam interface dengan komputer, elemen pemanas dan kipas sebagai output rangkaian yang diaktifkan oleh modul relai.

Pada Gambar 1, diperlihatkan blok diagram dari rancangan alat pencetak sedotan, pada blok diagram menggunakan empat push button untuk mengatur kerja alat dari pengaturan waktu pemanas sampai alat berhenti. Pada penelitian ini digunakan sensor suhu tipe DS18B20 karena memiliki tingkat sensitivitas yang cukup baik seperti dinyatakan oleh Irawan,dkk pada hasil penelitiannya (Irawan, dkk, 2020). Hal yang sama juga dijelaskan pada hasil penelitian oleh Ekayana, bahwa penggunaan sensor suhu tipe DS18B20 memiliki tingkat senstitivitasnya yang cukup baik untuk mengukur parameter suhu pada boks pencetak sedotan yang berbentuk bangun ruang (Ekayana, 2020). 


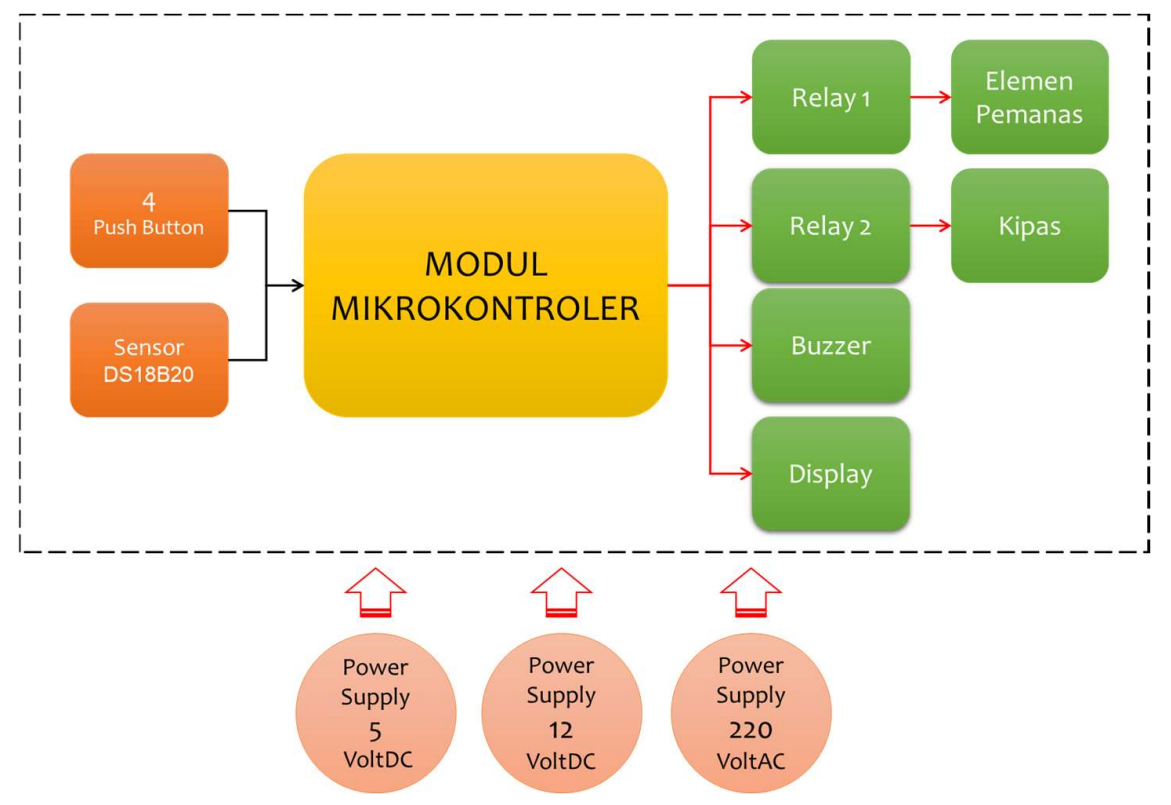

Gambar 1. Gambaran Umum Alat Pencetak Edible Straw

Pada bagian modul mikrokontroler menggunakan mikrokontroler tipe Arduino Uno, agar lebih efisien dalam melakukan perancangan dan perubahan pada alat dan mikrokontroler tipe ini tidak memerlukan perangkat tambahan dalam interface ke dalam komputer. Pada hasil penelitian oleh Sari \& Elfizon yang berjudul Alat Pengering Biji Kopi Berbasis Android (Sari \& Elfizon, 2020), menjelaskan bagian output dari alat pencetak sedotan menggunakan elemen pemanas jenis foildengan selaput Aluminium, untuk menjaga aliran listrik menjadi panas tetap aman di alat pencetak, dan menggunakan kipas DC sebanyak dua buah sebagai pendinginan proses pencetakan sedotan. Catu daya atau power supply yang digunakan terbagi menjadi tiga bagian, yaitu tegangan 5 Vdc untuk sensor, push button dan mikrokontroler, tegangan 12 Vdc untuk menghidupkan kipas dan tegangan 220 Vac sebagai sumber elemen pemanas. Adonan bahan cetakan edible straw dibuat menggunakan agar-agar kemasan dengan takaran satu bungkus agar-agar ditambahkan air sebanyak 500 ml, kemudian dipanaskan setelah itu adonan dituang pada cetakan sedotan.

\subsection{Perancangan Mekanik}

Perancangan mekanik alat pencetak sedotan menggunakan plat aluminium dan stainless steel sebagai bahan pembuatannya, hasil penelitian dari Harmanto, dkk yang berjudul Pengaruh Temperatur Cetakan Logam Terhadap Kekerasan Pada Bahan Aluminium Bekas (Harmanto, dkk, 2016) menjelaskan penggunaan aluminium memiliki kelebihan yaitu anti karat terhadap kelembapan di luar ruangan, ringan dan dapat menjaga suhu di dalam tetap stabil. Perancangan mekanik alat pencetak terbagi menjadi dua bagian, yaitu bagian pencetak sedotan berbentuk silinder menggunakan bahan stainless steel dan bagian pemanas dan pendingin cetakan berbentuk persegi menggunakan aluminium. Dimensi dari mekanik pencetak sedotan memiliki ukuran panjang $17 \mathrm{~cm}$ dan diameter lubang sedotan $1 \mathrm{~cm}$ serta diameter luar sedotan $1,5 \mathrm{~cm}$. Ukuran boks pemanas dan pendingin memiliki ukuran panjang $20 \mathrm{~cm}$, lebar $20 \mathrm{~cm}$ dan tinggi $10 \mathrm{~cm}$. Jumlah cetakan sedotan yang dibuat sejumlah empat buah. Adapun bentuk mekanik dari alat pencetak sedotan ditampilkan pada Gambar 2. 


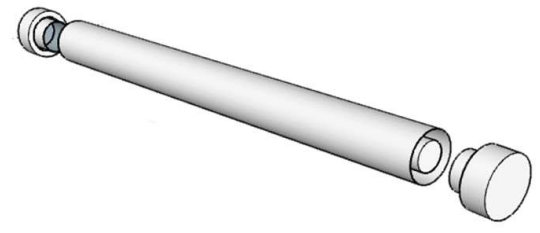

\section{Gambar 2. Bentuk Penampang Cetakan Sedotan}

Perancangan mekanik cetakan sedotan menyesuaikan dengan ukuran sedotan yang familiar digunakan oleh masyarakat, panjang $17 \mathrm{~cm}$ dan diameter lubang sedotan $1 \mathrm{~cm}$. Bahan pencetak sedotan menggunakan logam stainless steel, agar tetap higienis dalam proses pembuatanya.

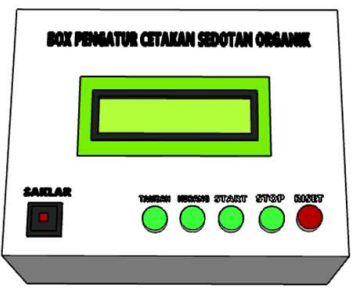

(a)

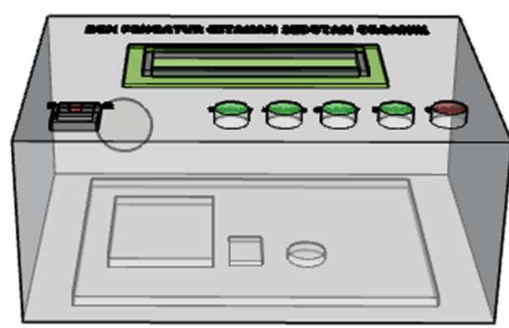

(b)

Gambar 3. (a) Bentuk Tampilan Depan dan (b) Tampak Dalam Boks Kontrol Alat Pencetak Sedotan

Pada Gambar 3 di atas, diperlihatkan bentuk dari boks kontrol alat pencetak sedotan, bahan material yang digunakan menggunakan aluminium, agar lebih kokoh dan solid terhadap suhu. Pada tampilan depan boks dipasang LCD, saklar on/offdan tombol Push Button sebagai tombol kontrol pemanas dan pendingin dari cetakan sedotan. Bagian dalam dari boks kontrol diletakkan modul mikrokontroler Arduino Uno dan blok relai untuk trigger elemen pemanas dan kipas.

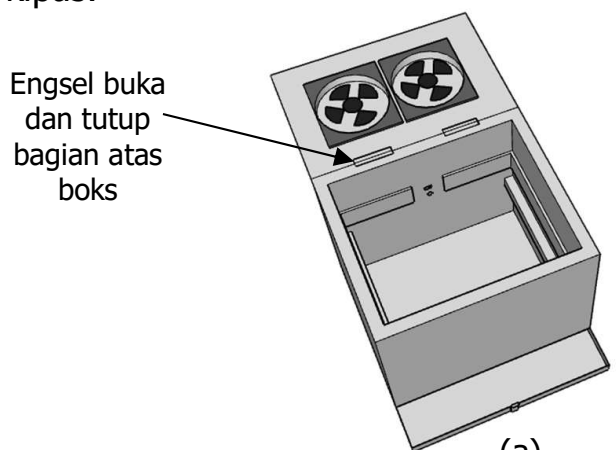

(a)

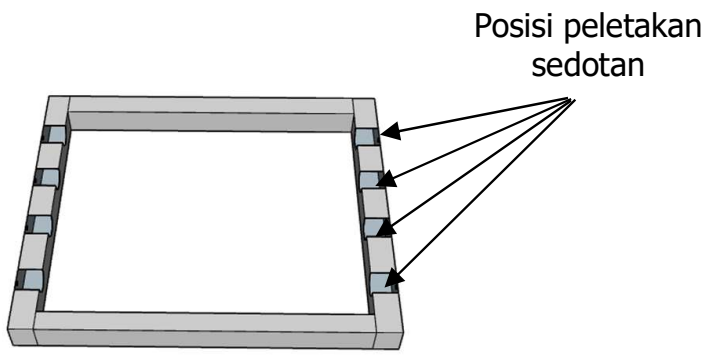

(b)

Gambar 4. (a) Bentuk Ruang Pemanas dan Pendingin Posisi Terbuka dan (b) Letak Cetakan Sedotan

Bentuk ruang pemanas dan pendinginan dari cetakan sedotan diperlihatkan pada Gambar 4, dirancang sedemikian rupa untuk dapat menampung empat cetakan yang bertujuan agar dimensi dari boks tidak terlalu besar dan jarak antar cetakan di dalamnya tidak terlalu sempit.

$$
\text { ELKOMIKA - } 956
$$


Cetakan sedotan di masukan ke dalam boks pemanas dan pendinginan, di mana penempatan elemen pemanas diletakkan disepanjang dinding boks untuk mendapatkan panas yang merata dan kipas sebagai proses pendinginan diletakkan pada bagian atas boks, agar angin yang disemburkan lebih menyeluruh ke dalam boks.

\subsection{Perancangan Sistem Elektronika}

Perancangan sistem elektronika dari alat pencetak edible straw menggunakan komponenkomponen yang mendukung dalam proses kerja alat, pembuatan skematik alat seperti yang diperlihatkan pada Gambar 5, memberikan penjabaran penggunaan pin dari blok input, blok proses dan blok output. Penempatan dari blok push button sebagai pusat pengatur menggunakan pin 9-12 dari mikrokontroler dan pin 2 mikrokontroler sebagai input dari sensor suhu DS18B20. Elemen pemanas dan kipas dihidupkan oleh blok relai untuk proses hidup dan mati, pin 6 mikrokontroler terhubung dengan blok relai untuk trigger elemen pemanas dan pin 7 terhubung dengan relai untuk menghidupan kipas DC. Bentuk gambar skematik dari sistem elektronika alat pencetak sedotan dapat dilihat pada Gambar 5.

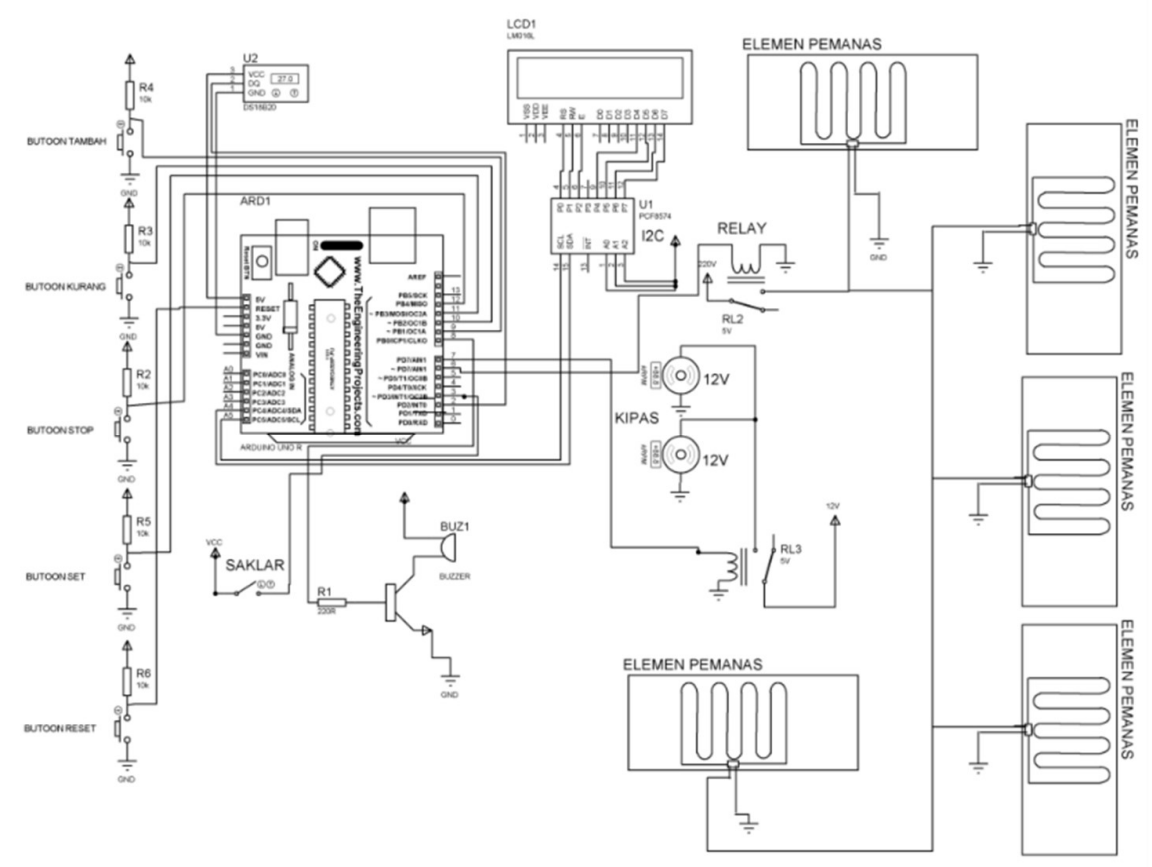

Gambar 5. Perancangan Skematik Alat Pencetak Sedotan

Bagian display alat pencetak sedotan menggunakan LCD 16×2 dengan modul I2C sebagai konektivitas ke mikrokontroler. Penggunaan LCD pada alat sebagai tampilan dari proses pengaturan waktu pemanasan, dan pendinginan pada proses kerja alat. Komponen output buzzer digunakan sebagai indikator saat proses pemanas dan pendinginan telah selesai bekerja. Alat pencetak sedotan dilengkapi juga dengan tombol reset, untuk mengatur kembali waktu pemanasan dan pendinginan, jika waktu yang sebelumnya kurang mendapatkan hasil cetakan sedotan yang baik. 


\subsection{Perancangan Flowchart dan Perangkat Lunak}

Pada perancangan perangkat lunak disusun diagram alir atau flowchart dari alat pencetak sedotan, perancangan flowchart memberikan gambaran proses kerja (Widiartha \& Ekayana, 2020) dari alat yang dirancang, sehingga memudahkan dalam pengoperasian dan troubleshooting. Rancangan diagram alir dari alat pencetak sedotan ditampilkan pada Gambar 6.

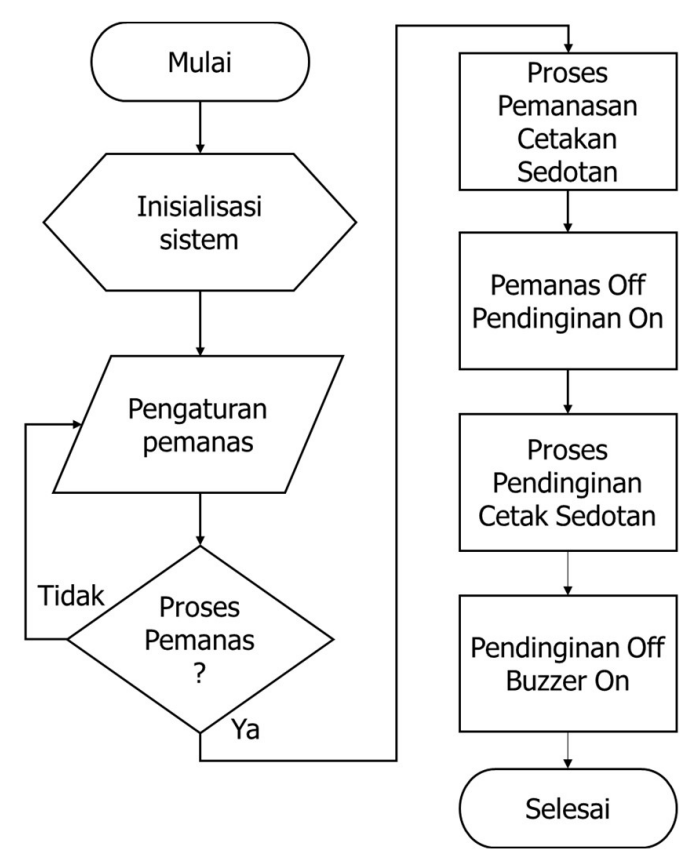

\section{Gambar 6. Diagram Alir Desain Alat Pencetak Edible Straw}

Proses unjuk kerja alat pada flowchart dimulai dari inisialisasi sistem, yaitu pada sensor, mikrokontroler dan output. Jika proses inisialisasi selesai selanjutnya dilakukan pengaturan waktu proses pemanasan sedotan dengan range waktu 5-30 menit, saat tombol mulai pada boks kontrol ditekan, maka alat akan bekerja memanaskan cetakan sedotan dengan waktu yang telah diatur sebelumnya. Variasi temperatur tidak langsung diatur melainkan waktu pemanas yang diatur, sehingga variasi temperatur antara waktu 5 menit berbeda dengan temperatur 30 menit. Saat waktu pemanas telah selesai selanjutnya kipas akan menyala untuk proses pendinginan cetakan sedotan, proses pendinginan diatur tetap selama 20 menit, waktu pendinginan diatur selama 20 menit, hal ini bertujuan memberikan pendinginan yang merata baik boks pemanas dan cetakan sedotan, proses ini bertujuan agar cetakan sedotan lebih cepat mengeras, jika proses pendinginan telah selesai maka buzzer menyala sebagai tanda alat pencetak telah selesai bekerja.

Perancangan selanjutnya yaitu perancangan program untuk alat pencetak sedotan menggunakan aplikasi bawaan dari Arduino yaitu Arduino IDE. Proses perancangan program dimulai dari pengaturan variable dan pin input output yang telah dibuat pada rancangan sistem elektronika. Jika proses perancangan dan pembuatan program selesai dilakukan, dilanjutkan dengan proses compile program, untuk memastikan tidak ada error yang terjadi. Tahap akhir dari perancangan perangkat lunak adalah mentransfer program ke dalam mikrokontroler, agar mikrokontroler dapat bekerja sesuai algoitma yang telah dibuat pada program. 


\section{HASIL DAN PEMBAHASAN}

Implementasi yang pertama dilakukan yaitu pembuatan cetakan dan boks pemanas. Cetakan dan boks pemanas sedotan dibuat dari material aluminium dan stainless steel. Dimensi keseluruhan dari boks pencetak sedotan yang telah dibuat berdimensi $20 \times 20 \times 20 \mathrm{~cm}$. Pada bagian dalam boks terdapat sensor suhu DS18B20, dibagian dalam boks terdapat lima elemen pemanas yang mengelilingi boks, terdapat juga dua kipas pendingin dan tempat penampungan jika ada air yang muncul selama proses pecetakan sedotan. Bentuk dari alat pencetak sedotan secara keseluruhan ditampilkan pada Gambar 7.

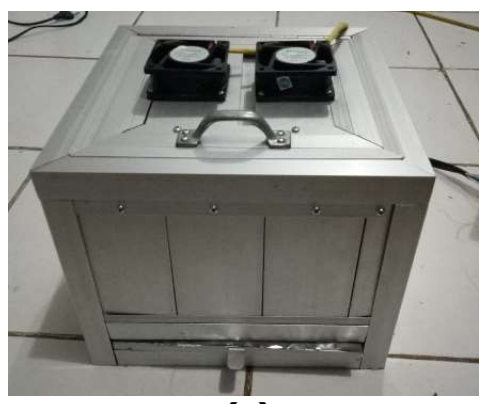

(a)

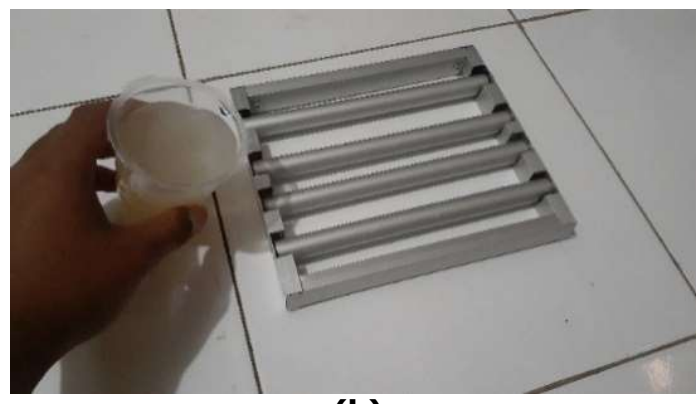

(b)

Gambar 7. (a) Boks Pemanas dan (b) Cetakan Sedotan

Pembuatan cetakan dan boks pemanas dibuat sedemikian rupa agar dalam proses kerjanya dapat sesuai dengan harapan yang direncanakan. Adonan dari bahan pembuat sedotan menggunakan bahan makanan yang sudah terdaftar BPOM, yaitu menggunakan agar-agar rumput laut yang banyak dijual di pasaran, selanjutnya jika adonan sudah selesai dituang pada cetakan dan dimasukkan pada boks untuk proses lebih lanjut.

\subsection{Pengujian Sensor Suhu}

Sensor suhu DS18B20 yang digunakan pada alat pencetak sedotan edible straw perlu dilakukan kalibrasi (Syahputra, dkk, 2014) dengan alat ukur baku, alat ukur termometer yang digunakan jenis termometer ruangan dengan tipe HTC-2 untuk mendapatkan hasil yang akurat selama proses kerja dari alat pencetak sedotan. Proses kalibrasi dilakukan untuk mendapatkan rata-rata pengujian yang sama dengan alat ukur baku dan minim terjadi error selama pengukuran. Adapun hasil kalibrasi sensor dengan alat ukur baku ditampilkan pada Gambar 8.

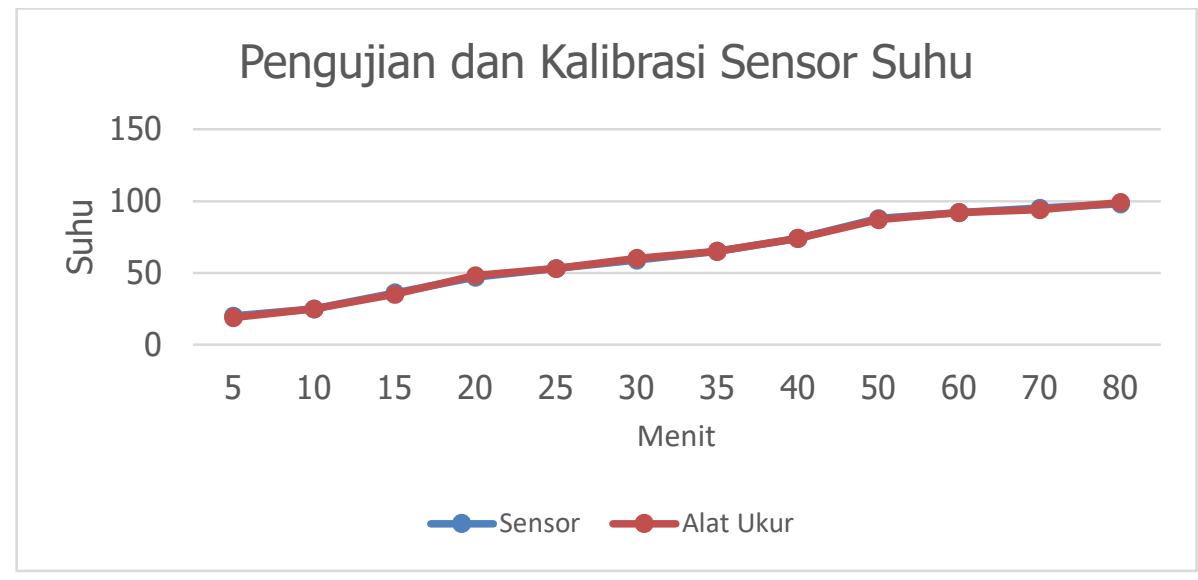

Gambar 8. Hasil Pengujian Sensor Suhu

ELKOMIKA - 959 
Proses kalibrasi dilakukan dengan cara menempatkan sensor suhu dan termometer pada boks pencetak sedotan, dan dilakukan proses pemanas dan pendinginan secara bertahap. Saat proses kalibrasi sensor suhu dengan termometer, didapatkan hasil pengukuran suhu pada waktu 5 menit sebesar $20^{\circ} \mathrm{C}$ dan pada waktu 80 menit didapatkan hasil pengukuran sebesar $99^{\circ} \mathrm{C}$. Tempat saat melakukan kalibrasi dilakukan di luar ruangan dan cuaca di lingkungan tempat tinggal tergolong sejuk, berbeda dengan daerah kota yang suhu ruang atau suhu daerah tersebut masuk pada range $25^{\circ} \mathrm{C}-27^{\circ} \mathrm{C}$, sehingga proses kalibrasi awal mendapatkan pengukuran suhu sebesar $20^{\circ} \mathrm{C}$.

Tahap pengujian selanjutnya yaitu melakukan pengujian pada pengatur waktu pemanas dan timer pada boks kontrol, pengujian ini dilakukan untuk memastikan waktu minimal dan waktu maksimal yang dapat atur pada boks pemanas. Pengaturan waktu pemanas dan tampilan timer alat pencetak sedotan ditampilkan pada Gambar 9.

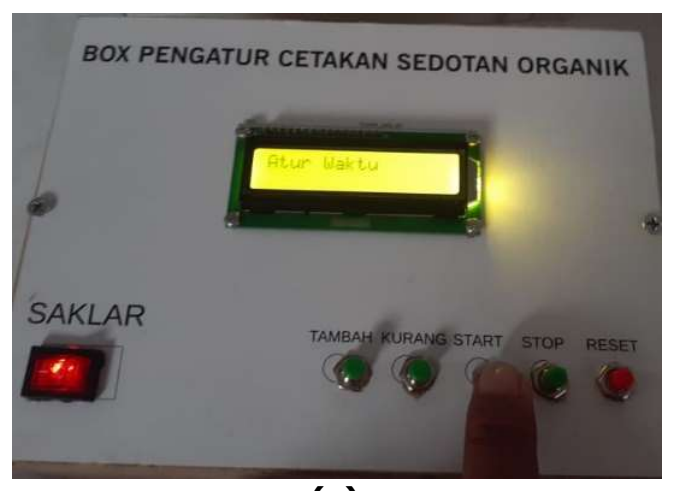

(a)

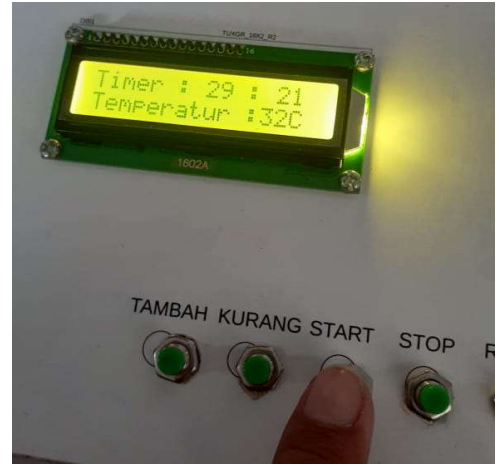

(b)

Gambar 9. (a) Pengujian Pengaturan Waktu dan (b) Timer Alat Pencetak Sedotan

Dari kesuluruhan pengujian yang telah dilakukan, didapatkan hasil yang cukup baik pada hasil pengujian masing-masing komponen penyusunnya. Hasil pengujian sensor suhu dengan alat ukur baku terdapat selisih pengukuran, dimana selisih yang terjadi masih bisa ditoleransi dengan kata lain hasil pengukuran menggunakan sensor suhu DS18B20 dapat digunakan untuk melakukan pengukuran pada alat pencetak sedotan selanjutnya. Hasil pengujian boks kontrol untuk pengaturan waktu pemanas dan pendinginan mendapatkan hasil yang baik, dimana semua tombol berfungsi dengan baik dan elemen pemanas serta kipas berkerja sesuai pangaturan yang sudah ditetapkan.

\subsection{Pengujian Keseluruhan Alat}

Setelah melakukan pengujian sensor dan kontrol dari alat pencetak sedotan, dan hasil yang didapatkan sesuai dengan rencana yang telah ditetapkan, selanjutnya dilakukan pengujian keseluruhan alat, dimana adonan untuk bahan cetakan sedotan telah disiapkan, di masukan ke dalam cetakan dan diposisikan di dalam boks pemanas. Pengujian keseluruhan alat dilakukan sebanyak lima kali yang disesuaikan dengan waktu yang telah diatur sebelumnya, di mana range waktu yang diberikan antara 5-30 menit. Hasil pengujian keseluruhan alat mendapatkan hasil seperti yang terlihat pada Tabel 1 . 
Tabel 1. Pengujian Alat Pencetak Sedotan Keseluruhan

\begin{tabular}{|c|c|c|c|c|c|c|c|c|c|c|c|}
\hline \multirow{2}{*}{ No } & \multicolumn{9}{|c|}{$\begin{array}{c}\text { Waktu Pengujian sensor suhu } \\
\text { (Menit) }\end{array}$} & \multicolumn{6}{c|}{$\begin{array}{c}\text { Waktu Pengujian termometer } \\
\text { (Menit) }\end{array}$} \\
\cline { 2 - 16 } & & 5 & 10 & 15 & 20 & 30 & 5 & 10 & 15 & 20 & 30 \\
\hline 1 & 1 & 20 & 24 & 38 & 50 & 62 & 20 & 22 & 36 & 50 & 60 \\
\hline 2 & 2 & 20 & 23 & 37 & 50 & 61 & 20 & 22 & 36 & 50 & 60 \\
\hline 3 & 3 & 20 & 24 & 38 & 49 & 62 & 20 & 22 & 36 & 49 & 60 \\
\hline 4 & 4 & 21 & 24 & 38 & 50 & 62 & 20 & 22 & 36 & 49 & 60 \\
\hline 5 & 5 & 20 & 24 & 38 & 50 & 62 & 20 & 22 & 36 & 49 & 60 \\
\hline Rata-rata suhu terukur & 20.2 & 23.8 & 37.8 & 49.8 & 61.8 & 20 & 22 & 36 & 49.4 & 60 \\
\hline $\begin{array}{l}\text { Selisih sensor suhu } \\
\text { dengan termometer }\left({ }^{\circ} \mathrm{C}\right)\end{array}$ & 0.2 & 1.8 & 1.8 & 0.4 & 1.8 & & & & \\
\hline $\begin{array}{l}\text { Standar Deviasi sensor } \\
\text { suhu }\end{array}$ & 0.4 & 0.4 & 0.4 & 0.4 & 0.4 & & & & \\
\hline
\end{tabular}

Pada Tabel 1, hasil pengujian keseluruhan sistem yang dilakukan pada alat pencetak sedotan mendapatkan data saat pengukuran suhu pada ruang pemanas, penelitian yang dilakukan (Afdali, dkk, 2017) mengambil cara perhitungan dari proses pengukuran. Pengujian dilakukan sebanyak 5 kali dengan pada jarak waktu 5 - 30 menit, dari data yang didapatkan selanjutnya dilakukan perhitungan untuk mencari rerata sensor suhu, selisih suhu terukur dengan termometer dan standar deviasi dari sensor suhu. Rerata suhu terukur secara rinci dapat dilihat pada Tabel 1, untuk selisih suhu sensor dengan termometer yang paling kecil didapatkan sebesar 0.2 pada waktu 5 menit dan tertinggi sebesar 1.8 pada waktu 10, 15 dan 30 menit. Perhitungan standar deviasi dari sensor suhu didapatkan semua bernilai positif, di mana kestabilan sistem akan tergambarkan oleh nilai standar deviasi (yang nilainya selalu positif) dan nilai rata-rata dari pengujian.

Hasil dari alat pencetak sedotan menghasilkan sedotan terbuat dari bahan makanan agar-agar rumput laut merek Nutrijell yang sudah terdaftar di BPOM dan aman dikonsumsi saat proses pencetakan selesai, takaran adonan yang digunakan pada penelitian ini yaitu satu bungkus agar-agar dengan merek Nutrijell dengan campuran air sebanyak $500 \mathrm{ml}$, dari proses pengujian alat pencetak sedotan terdapat tiga model sedotan yang dihasilkan, Ketiga hasil tersebut dibuat dengan pengaturan waktu pemanas yang berbeda-beda. Pada Gambar 10, diperlihatkan hasil sedotan yang telah selesai dibuat dengan pengaturan pemanas selama 15 menit dan pendinginan 20 menit. Waktu pendinginan diberikan selama 20 menit karena berdasarkan pengujian, pendinginan ruang pemanas dan cetakan waktu 20 menit dirasa cukup untuk mengurangi kadar air pada cetakan sedotan dan cetakan dapat diambil secara langsung karena kadar panas sudah berkurang. 


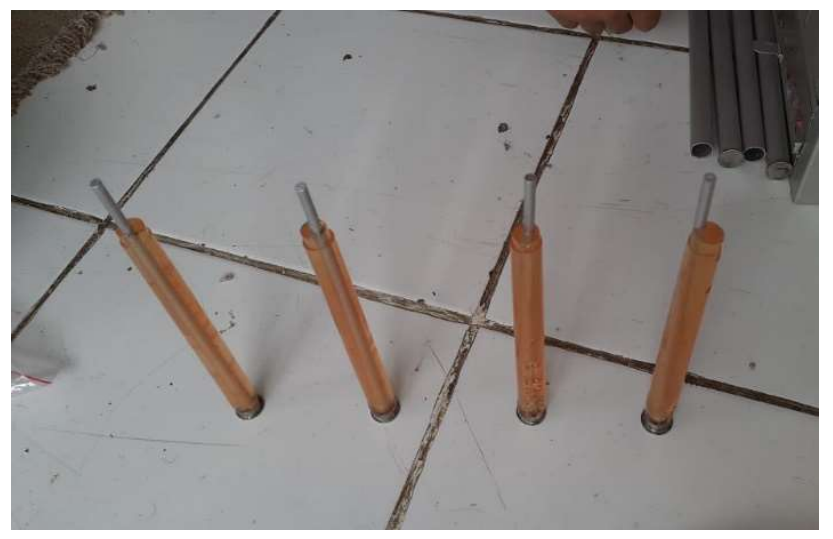

Gambar 10. Hasil Sedotan Organik Yang dipanaskan Selama 15 Menit

Sedotan yang dipanaskan selama 15 menit, mendapatkan hasil masih bertekstur kenyal berair, karena proses pemanas masih belum cukup untuk mendapatkan hasil yang lebih kaku dan kokoh.

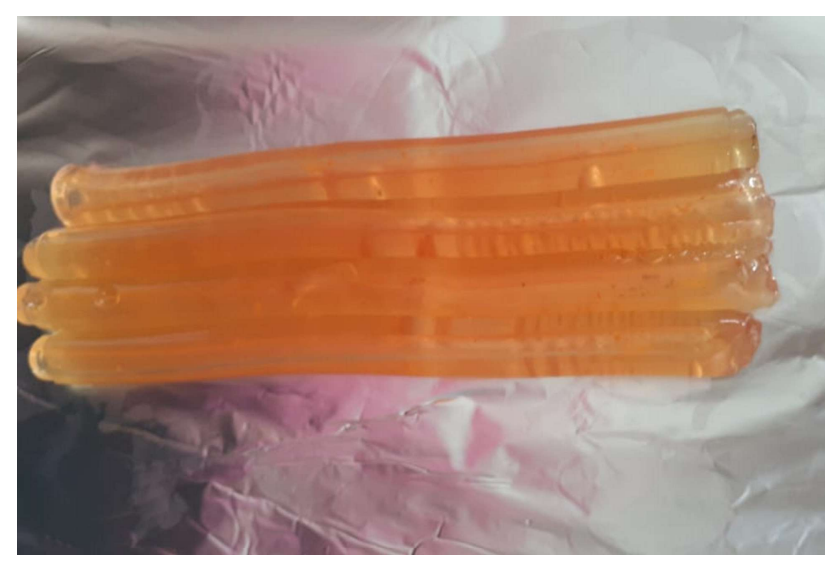

\section{Gambar 11. Hasil Sedotan yang dipanaskan Selama 20 Menit}

Selanjutnya hasil cetakan sedotan yang dipanaskan selama 20 menit dengan proses pendinginan 20 menit, mendapatkan hasil yang kenyal, hanya saja masih belum kokoh untuk digunakan, karena masih ada kandungan air di dalam sedotan yang cukup banyak.

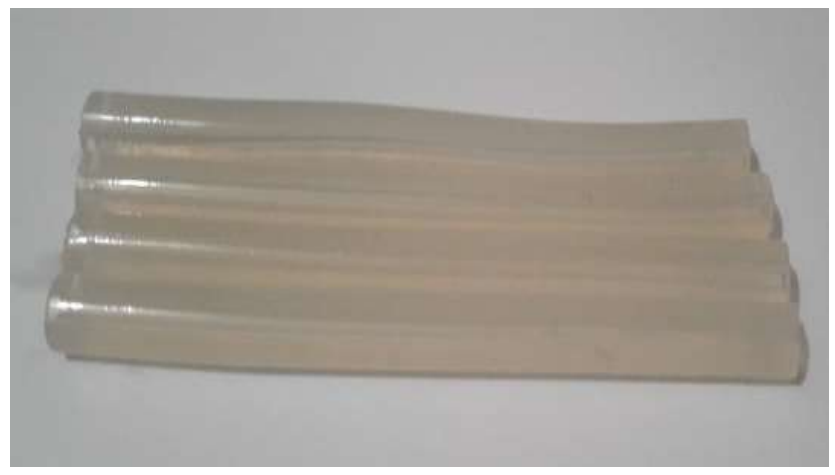

Gambar 12. Hasil Sedotan Yang Dipanaskan Selama 30 Menit 


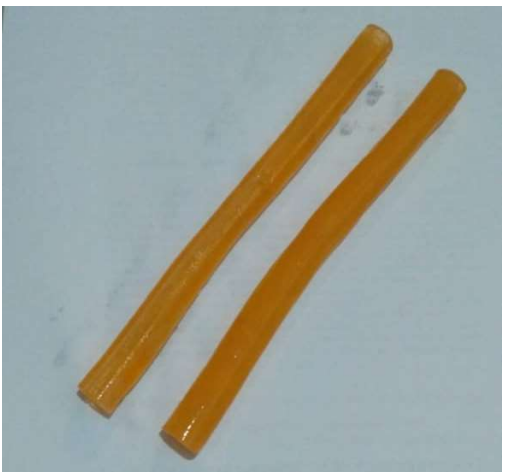

(a)

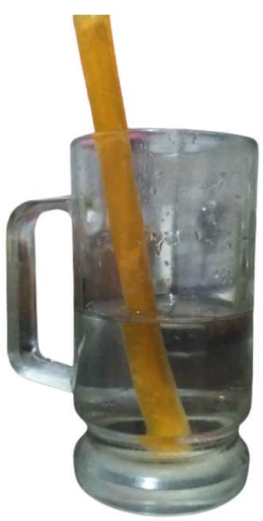

(b)

Gambar 13. (a) Sedotan yang baru Selesai Dicetak dan (b) Keadaan Posisi Sedotan (edible straw) sigunakan di dalam Gelas

Hasil alat pencetak sedotan yang dipanaskan selama 30 menit dan pendinginan selama 20 menit mendapatkan hasil yang cukup baik, dimana kandungan air pada sedotan sudah berkurang, diameter lubang sesuai dengan cetakan, dan bentuk sedotan sudah bisa berfungsi seperti sedotan pada umumnya. Warna pada sedotan tidak mempengaruhi hasil cetakan, karena warna tersebut merupakan rasa pada agar-agar rumput laut yang digunakan, warna jingga dengan rasa mangga dan warna putih dengan rasa leci. Pengujian sedotan sudah dilakukan pada gelas yang berisi minuman, sedotan yang dihasilkan selanjutnya dilakukan pengujian ketahanan bentuk pada gelas yang berisi minuman, sedotan kehilangan daya berdiri (letoi) saat dibiarkan selama 30 menit di dalam gelas yang berisi minuman dan sedotan terlarut pada waktu 60 - 120 menit. Pada Gambar 13 terlihat bentuk sedotan saat digunakan di dalam gelas yang berisi minuman.

\section{KESIMPULAN}

Desain alat pencetak edible straw berbasis mikrokontroler telah berhasil dirancang dan dibangun menggunakan komponen-komponen elektronika, dimana diantaranya sensor suhu DS18B20, modul mikrokontroler, relai, elemen pemanas dan kipas. Alat pencetak sedotan menggunakan bahan aluminium untuk boks pemanas dan stainless stee/ untuk bahan cetakan sedotan. Proses pencetakan sedotan diatur dari waktu minimal yaitu 5 menit sampai waktu maksimal 30 menit, dengan proses pendinginan ditetapkan selama 20 menit. Proses pengujian dan kalibrasi sensor suhu dilakukan terlebih dahulu untuk memastikan bahwa sensor dapat mengukur parameter suhu sesuai dengan alat ukur baku. Hasil dari pengujian mendapatkan data yang cukup baik antara pembacaan sensor suhu dan termometer, sehingga bisa digunakan dalam pengujian keseluruhan alat. Proses pengujian keseluruhan alat dilakukan sebanyak 5 kali yang disesuaikan dengan range waktu yaitu 5-30 menit, dari hasil pengujian didapatkan standar deviasi dari sensor suhu bernilai positif, dimana kestabilan sistem akan tergambarkan oleh nilai standar deviasi (yang nilainya selalu positif) dan nilai rata-rata dari pengujian. Hasil akhir dari proses pencetak sedotan yaitu kualitas hasil cetak yang cukup bervariasi, dimana hasil dari cetakan sedotan ini dipengaruhi oleh lamanya waktu pemanasan, sehingga kandungan air pada sedotan semakin berkurang dan sedotan dapat digunakan sebagaimana fungsinya. Sedotan dengan hasil terbaik diperoleh dengan dipanaskan selama 30 menit dari suhu awal dengan suhu terukur pada menit ke-30 adalah $62^{\circ} \mathrm{C}$. hasil penelitian

$$
\text { ELKOMIKA - } 963
$$


ini menghasilkan sedotan dengan bahan makanan yang sudah berstandar BPOM, keunggulan sedotan edible straw dapat digunakan sebagaimana sedotan pada umumnya dan dapat dikonsumsi, sehingga timbulan sampah plastik dari pipet dapat dikurangi.

Saran dan masukan untuk pengembangan selanjutnya yaitu perlu mempertimbangkan bentuk cetakan sedotan yang lebih baik, terutama pada bagian penutup cetakan agar hasil cetakan sedotan menjadi lebih rapi. Posisi penempatan cetakan di dalam boks pemanas bisa dibuat posisi berdiri untuk memberikan ruang yang lebih banyak untuk cetakan yang dibuat dan penempatan posisi vertikal untuk menjaga kandungan air pada proses pemanasan pada satu titik yaitu di bagian bawah cetakan.

\section{UCAPAN TERIMA KASIH}

Ucapan terimakasih ditujukan kepada Lembaga Penelitian dan Pengabdian Masyarakat yang telah memberikan kesempatan untuk melakukan penelitian PDM dengan nomor kontrak 13/04/LPPM/PDM/V/2021 dan institusi STMIK STIKOM Indonesia sebagai penyandang dana penelitian ini

\section{DAFTAR RUJUKAN}

Afdali, M., Daud, M., \& Putri, R. (2017). Perancangan Alat Ukur Digital untuk Tinggi dan Berat Badan dengan Output Suara berbasis Arduino UNO. Jurnal Elkomika, 5(1), 106-118. https://doi.org/10.26760/elkomika.v5i1.106

Aritonang, W., Bangsa, I. A., \& Rahmadewi, R. (2021). Implementasi Sensor Suhu DS18B20 dan Sensor Tekanan MPX5700AP menggunakan Mikrokontroller Arduino Pada Alat Pendeteksi Tingkat Stress. Jurnal IImiah Wahana Pendidikan, オ1), 153-160. https://doi.org/10.5281/zenodo.4541278

Dahwilani, D. M. (2019). Data dan Fakta Tren Menjamurnya Kedai Kopi Kekinian di Indonesia. INews.id. https://www.inews.id/travel/kuliner/data-dan-fakta-tren-menjamurnya-kedaikopi-kekinian-di-indonesia

Ekayana. (2020). Implementasi Dan Analisis Data Logger Sensor Temperature Menggunakan Web Server Berbasis Embedded System. Jurnal Pendidikan Teknologi dan Kejuruan, 171), 64. https://doi.org/10.23887/jptk-undiksha.v17i1.22411

Ekayana, A. A. G. (2016). Rancang Bangun Alat Pengering Rumput Laut Berbasis Mikorokontroler Arduino Uno. Jurnal Pendidikan Teknologi dan Kejuruan, 13(1), 1-12.

Harmanto, S., Supriyadi, A., \& Wattimena, R. M. (2016). Pengaruh Temperatur Cetakan Logam Terhadap Kekerasan Pada Bahan Aluminium Bekas. Jurnal Rekayasa Mesin, 11, 5.

Irawan, A. I., Patmasari, R., \& Hidayat, M. R. (2020). Peningkatan Kinerja Sensor DS18B20 pada Sistem IoT Monitoring Suhu Kolam Ikan. JTERA (Jurnal Teknologi Rekayasa). https://doi.org/10.31544/jtera.v5.i1.2019.101-110 
Nugroho, E. C., Nugroho, A., \& Hendriyanto, I. (2019). Prototipe Mesin CNC 2D Berbasis Arduino Uno. Go Infotech: Jurnal IImiah STMIK AUB, 25(1), 43. https://doi.org/10.36309/goi.v25i1.103

Pratama, E. B. (2020). Perancangan Motion Graphic Dampak Plastik Di Laut. Jurnal Desain Komunikasi Visual, 4(1), 525-540.

Qomariah, N. (2020). Sosialisasi Pengurangan Bahan Plastik Di Masyarakat. Jurnal Pengabdian Masyarakat, 1(1), 43-55.

Rusli, A., LLijas, M. I., Alias, M., \& Budiman. (2020). Strategi pengelolaan budidaya rumput laut Kappaphycus alvarezii. Agrokompleks, 20(1), 28-38.

Sari, R. G., \& Elfizon. (2020). Alat Pengering Biji Kopi Berbasis Android. Jurnal Teknik Elektro Indonesia, 1(2), 212-217.

Sujana, I. W., Al Zarliani, W. O., \& Hastuti, H. (2020). Pemberdayaan Ekonomi Masyarakat Pesisir Melalui Pengolahan Rumput Laut. Jurnal Pengabdian Kepada Masyarakat MEMBANGUN NEGERI, 4(1), 24-33. https://doi.org/10.35326/pkm.v4i1.573

Syahputra, H., Umar, L., \& Setiadi, R. n. (2014). Automatisasi Kalibrasi Sensor Suhu Ptc Dan Ntc Mempergunakan Sumber Tegangan Terprogram Dac7611. Pengaruh Harga Diskon Dan Persepsi Produk Terhadap Nilai Belanja Serta Perilaku Pembelian Konsumen, 1(9), 178-184.

Widiartha, K. K., \& Ekayana, A. A. G. (2020). Design of IOT based facial recognition door access control locker services at tourist attractions in Bali. Journal of Physics: Conference Series, 1516(1). https://doi.org/10.1088/1742-6596/1516/1/012028

Wirajaya, M. R., Abdussamad, S., \& Nasibu, I. Z. (2020). Rancang Bangun Mesin Penetas Telur Otomatis Menggunakan Mikrokontroler Arduino Uno. Jambura Journal of Electrical and Electronics Engineering, 2(1), 24-29. https://doi.org/10.37905/jjeee.v2i1.4579

Zainudin, A., Santoso, T., Wijayanti, A., Pratiarso, A., Sudarsono, A., Mahmudah, H., Siswandari, N. A., Budikarso, A., Syahroni, N., Wahyuningrat S., H., Siswanto, A., Juliansyah, F., Farhan, D., \& Susanti, T. (2020). Pemanfaatan Alat Monitoring Kadar Air Pada Gabah untuk Peningkatkan Kualitas Panen. DIKEMAS (Jurnal Pengabdian Kepada Masyarakat), 4(2), 49-56. https://doi.org/10.32486/jd.v4i2.457 